\title{
IDENTIFICATION OF AQUATIC PLANT SPECIES FROM BANTIMURUNG WATERFALL AND THEIR PHYTOCHEMICAL COMPOUNDS ANALYSIS
}

\author{
Media Fitri Isma Nugraha*1 Fasya Hadaina Maharani ${ }^{2}$, Hessy Novita $^{3}$, Muh Alias L \\ Rajamuddin $^{4}$, RossaYunita ${ }^{5}$, Reflinur ${ }^{5}$ Wening Enggarini $^{5}$, Atriyon Julzarika ${ }^{6}$, Berna Elya ${ }^{2}$ \\ ${ }^{1}$ Indonesian Research Center for Ornamental Fish - Research and Human Resources Agency-Ministry \\ Marine and Fisheries. \\ ${ }^{2}$ Laboratory of Pharmacognosy and Phytochemistry, Faculty of Pharmacy, Universitas Indonesia \\ ${ }^{3}$ Instalation of Research on The Development and Control of fish Disease - Research and Human \\ Resources Agency-Ministry Marine and Fisheries \\ ${ }^{4}$ Politeknik Pertanian Negeri Pangkajene Kepulauan. Pangkep, Sulawesi Selatan \\ ${ }^{5}$ Indonesian Center for Agricultural for Biotechnology and Genetic Resources Research and \\ Development - Ministry of Agricultural. \\ ${ }^{6}$ Indonesian National Institute of Aeronautics and Space (LAPAN)
}

\begin{abstract}
A total of 21 aquatic plant species were collected from Bantimurung waterfall areas, South Sulawesi, Indonesia, in October 2017. These plant materials were subjected to both species and phytochemicals identification. The aims of this study were to determine the species or taxonomic rank of Indonesian aquatic plants collected from Bantimurung waterfall, South Sulawesi, Indonesia and to identify their chemical compounds (phytochemicals) as a candidate for new herbal medicine. Plant genetic materials used in this study were collected from Bantimurung Bulusaraung waterfall and were then identified based on standard botanical techniques for species identification in the Herbarium Bogoriense, Research center for Biology Indonesian Institute of Science (LIPI), Cibinong, West Java. The samples were subjected to the phytochemistry screening such as alkaloids, flavonoids, tannins, saponins, glycosides, terpenoids and anthraquinone followed the procedures of Indonesian Materia Medika and Harborne. Results showed that all collected aquatic plant samples were able to be identified, including their species names. Phytochemical screening of each sample revealed the presence of glycoside in all of the tested species. However, no alkaloids, anthraquinones, and terpenoids were observed in those tested plant samples. Of the total 21 aquatic plants, 14 species contained flavonoids, 8 species contained phenol compound, and 10 species contained saponins. Among these species Donnax canniformis possessed good antioxidant activity, which correlated to its total phenolic and flavonoid contents. Our results would be beneficial for any future effort in the development of new herbal drugs derived from aquatic plants.
\end{abstract}

Key words: Aquatic plants, Antioxidant activity, Flavonoid, Phenolic,

*Corresponding author:

Jl. Perikanan No 13 Pancoran Mas Depok, West Java, Indonesia

E-mail: media.nugraha@kkp.go.id / mfitri_isman@yahoo.com

\section{Introduction}

Aquatic biodiversity is a sensitive thematic issue because it serves as a component of global biodiversity and a model for basic research on water ecological studies in evolutionary aquatic ecosystems (Xu et al., 2007). Aquatic plants act as "engineering and pioneer species" (Ansari et al., 2017), and their disappearance may have drastic effects on trophic and functional status of the habitats within water bodies (Bouma et al.,
2000; Scheffer et al., 2003). Nevertheless, aquatic plants often remain unrecognized in broad-scale investigations, a condition that can lead to wrong or to conflicting evaluations in analysing their current spatial patterns and rarity (Alahuhta et al., 2017).

Drought in the riverine areas can be examined by identifying the original source from which the water flows. Bantimurung is one of the regions that has a vast and long riverine area. It is believed that water plants can be an indicator to 
determine whether or not a particular aquatic ecosystem is healthy. The availability of water which falls into extremely low levels in a long period is required in order to keep the aquatic ecosystems stable. According to Parenti, (1998) the aquatic plants which grew along the vast riverine area affected water health and provided several benefits in fulfilling future human needs.

The existence of aquatic species reflects the condition of waters and ecosystems. Aquatic plant species from various families serve as reliable indicators for biological monitoring of aquatic ecosystems (Ansari et al., 2017). The loss of vulnerable species leads to changes in species composition and in ecosystems. Therefore, maintaining aquatic plant biodiversity and their adaptability to environmental changes, including climate change, is very important. Aquatic plant biodiversity plays a vital role in people's livelihood, but it is being threatened by many factors such as climate change. It is generally acknowledged that aquatic plants, despite representing only a small fraction of the total vascular plant diversity $(\sim 1 \%)$, are one of the most critical groups of threatened species worldwide (Saunders et al., 2002; Chambers et al., 2008).

Based on the Ramsar Convention of 10 June 2011, the total area of important Indonesian wetlands was 964,600 ha (Gopal, 2013). Bantimurung waterfall is located in Maros District, South Sulawesi Province, Indonesia, and the areas surrounding the waterfall and river have various plant species. Bantimurung area $(43,750$ ha) is located in Wallace line region with highly endemic and specific mix of flora and fauna between Asia and Australia (Wakka et al., 2012). Bantimurung is located in the early tertiary isolated small land area in Sulawesi, and this is probably the factor which caused the endemism of its flora and fauna. Based on the Wallace theory, many endemic and special flora and fauna live in this region because their range of diversity is often strongly related to suitable habitats and climate, or because certain floral elements were present on both sides of the Wallace line before the formation of Makassar straits (Parenti, 1998). In addition, Thomaz \& Cunha (2010) reported that waterfalls in mountains and rivers also support a rich assortment of aquatic biological diversity that contributes to the economy, culture, health (as the source of nutrition and medicine), and social recreation of human beings. Experiments with several aquatic plants reported by Gesberg et al., (1986) could act as a medium for waste water treatment and removed ammonia, nitrogen TSS (Total Suspended Solids), and BOD (Biochemical Oxygen Demand). Although, studies on numerous phytochemicals derived from different plants have been published, but only few studies reported such as phytochemicals investigated from aquatic plants. A broad body of knowledge about chemical compounds resulting from aquatic plants serves as a valuable material for developing traditional medicine in future. Therefore, we have to give more attention to the biodiversity of aquatic plant species and the prospect for developing them into herbal drugs for fish and humans.

Aquatic plant biodiversity has a great potential for bringing about new pharmaceutical inventions derived from fresh water aquatic flora. It is expected that those species can contribute to food security and meet future challenges in the development of new herbal drugs for controlling fish or human diseases. This paper provides the first comprehensive inventory and phytochemical analysis of endemic aquatic plants found in Bantimurung, South Sulawesi Province, Indonesia. The aims of this study were to identify the diversity of aquatic plant resources collected from Bantimurung waterfall zones and to analyse their potential phytochemicals as a candidate for new herbal medicines

\section{Materials and Methods}

\section{Study area}

A total of 21 aquatic plants samples were collected from the areas surrounding Bantimurung Bulusaraung waterfall, Maros District, South Sulawesi Province, Indonesia, from October 2017. Sampling site was determined according to the remote sensing data from the preliminary location surveys and geobiophysical information provided by WorldView-2 satellite imageries (Indonesian National Institute of Aeronautics and SpaceLAPAN)

The aquatic plants were identified based on standard botanical techniques for species identification in the Herbarium Bogoriense, Research center for Biology Indonesian Institute of Science (LIPI), Cibinong, West Java. The fresh samples were washed with tap water to remove impurities on the sample surface and were dried in the greenhouse of the Indonesian Centre for Agricultural Biotechnology and Genetic Resources Research and Development 
(ICABIOGRAAD), Bogor. Those dried samples were powdered using a blender.

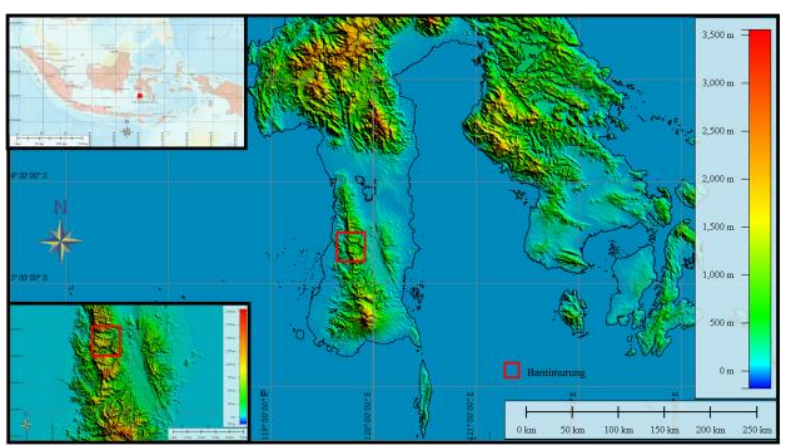

Figure 1. Bantimurung Bulusaraung National Park, South Sulawesi $\left(4^{0} 58^{\prime} 08.68^{\prime} \mathrm{S}\right.$ dan $119^{\circ}$ 40 '56.94' E); and the detected sites.

\section{Procedures and Data analysis}

\section{Chemical and Reagents}

The chemicals used in this study including gallic acid standard, quercetin standard, 1,1Diphenyl-2-picrylhydrazine (DPPH) were purchased from Sigma-Aldrich, Folin Ciocalteu's phenol, methanol for analysis, ethanol for analysis were purchased from Merck Indonesia.

\section{Extraction Procedure}

Aquatic plants samples were extracted according to the procedures described by Indonesian Materia Medika Departemen Kesehatan Republik Indonesia (1995) and Harborne, (1998). The dried powder sample (1 g) was diluted in $10 \mathrm{~mL}$ ethanol $70 \%$ and extracted using a sonicator for an hour. Then, the filtrate and the residue were separated using a funnel

\section{Phytochemistry screening}

The aquatic plants extracts were diluted using ethanol. Identification of the presence of Total phenolic content, flavonoid content, antioxidant activity, accordance with procedures of Indonesian Materia Medika Departemen Kesehatan Republik Indonesia. (1995) and Harborne, (1998).

\section{Determination of Total Phenolic Content}

The determination of total polyphenol content was performed using the 96-well microplate reader method $20 \mu \mathrm{L}$ of sample or standard was added to $100 \mu \mathrm{L}$ reagent of $25 \%$ Folin-Ciocalteu solution, which was homogenized for 1 minute and then allowed to stand for 4 minutes. Then, 75 $\mu \mathrm{L}$ of $10 \%$ sodium carbonate solution was added and homogenized for 1 minute. Mixed solutions were incubated for 2 hours at room temperature with dark condition. Gallic acid was used as the standard (Ahmad et al., 2017). The calibration curve of gallic acid which measured at a wavelength of $750 \mathrm{~nm}$ by using a microplate reader (VersaMax ${ }^{\mathrm{TM}}$ ELISA Microplate reader, USA) with equation $\mathrm{y}=0.047 \mathrm{x}+0.087 \mathrm{R}^{2}=$ 0.992 . The total phenolic contents of aquatic plants were measured using Folin Ciocalteu's method and were reported as gallic acid equivalents method by Bobo-Garcia et al., (2014) with some modifications. The yield of GAE in extracts was determined by comparing its absorbance with the standard.

\section{Determination of Total Flavonoid Content}

The total flavonoid content in aquatic plants was determined using the aluminium chloride colorimetric assay. $50 \mu \mathrm{l}$ of extracts or standard solution of quercitin $(6.25,12.5,25,50,100$ $\mu \mathrm{g} / \mathrm{ml}$ ) in $70 \%$ ethanol was added to $10 \mu \mathrm{l}$ of $10 \%$ aluminium chloride solution, followed by $150 \mu 1$ of $95 \%$ ethanol. $80 \%$ ethanol was used as reagent blank. $10 \mu \mathrm{l}$ of $1 \mathrm{M}$ sodium acetate was added to the mixture in a 96-well plate. All reagents were mixed and incubated for 40 minutes at room temperature, protected from light. The absorbance was measured at $415 \mathrm{~nm}$ using a Microplate Reader (VersaMax ${ }^{\mathrm{TM}}$ ELISA Microplate reader, USA). ${ }^{[19]}$

\section{Determination of antioxidant activity}

Antioxidant activity was determined using the 96-well plate assay as proposed in several previous studies (Bobo-García et al., 2014), with some modifications. A total of $20 \mu \mathrm{L}$ of sample solution was added to $180 \mu \mathrm{L}$ of DPPH solution $(300 \mu \mathrm{M})$ in methanol, and then was homogenized for $60 \mathrm{~s}$ in a microplate reader. The reagents were incubated for 40 minutes in the dark at room temperature. The absorbance was measured at $517 \mathrm{~nm}$ in a microplate reader. Quercetin was used as the standard.

$\%$ DPPH inhibition $=\frac{A \text { sample }-A \text { blanko }}{A \text { blanko }} \times 100 \%$

\section{Results}

\section{Determination of Plants}

The species of the collected plants were identified. They consisted of 14 families and 21 species of plants, as shown in Table 1 . 
Table 1. Name of aquatic plant list from waterfall Bantimurung Bulusaraung South Sulawesi

\begin{tabular}{|c|c|c|c|}
\hline No & Species Name & Famili & Part of Plant \\
\hline 1 & $\begin{array}{l}\text { Anadendrum microstachyum (de Vriese \& Miq.) Backer \& } \\
\text { Alderw }\end{array}$ & Araceae & Herbs \\
\hline 2 & Donax canniformis (G.Forst.) K. Schum. & Maranthaceae & Stem \& root \\
\hline 3 & Donax canniformis (G.Forst.) K. Schum. & Maranthaceae & Leaf \\
\hline 4 & Diplazium & Athyriaceae & Herbs \\
\hline 5 & Elatostema $\mathrm{sp}$ & Urticaceae & Leaf \\
\hline 6 & Epipremnum sp & Araceae & Herbs \\
\hline 7 & Hemigraphis sp & Acanthaceae & Herbs \\
\hline 8 & Lindsaea scandens Hook. & Lindsaeaceae & Herbs \\
\hline 9 & Murdannia sp & Commelinaceae & Herbs \\
\hline 10 & Oldelandia $\mathrm{sp}$ & Rubiaceae & Herbs \\
\hline 11 & Stenosemia aurita (Sw.) C. Presl & Tectariaceae & Leaf \\
\hline 12 & Staurogyne elongata Kuntze & Acanthaceae & Stem \& root \\
\hline 13 & Staurogyne elongata Kuntze & Acanthaceae & Leaf \\
\hline 14 & Staurogyne sp & Acanthaceae & Herbs \\
\hline 15 & Schismatoglottis calyptrata (Roxb.) Zoll. \& Moritzi & Araceae & Herbs \\
\hline 16 & Schismatoglottis sp & Araceae & Herbs \\
\hline 17 & Selaginella plana (Desv. Ex Poir.) Hieron. & Selaginellaceae & Herbs \\
\hline 18 & Senna alata (L.) Roxb & Leguminosae & Herbs \\
\hline 19 & Persicaria barbata (L.) H.Hara & Polygonaceae & Herbs \\
\hline 20 & Pellionia sp & Urticaceae & Herbs \\
\hline 21 & Pothos tener Wall & Araceae & Herbs \\
\hline
\end{tabular}

\section{Phytochemical Screening}

The result of phytochemical compounds obtained from 21 aquatic plant samples were presented in Table 2. Of these, flavonoid and glycoside were found in all the samples, phenol and saponin were detected only in several samples. While, there where no alkaloid, terpenoid and antraquinon were found in the samples.

\section{Total Flavonoid Contents}

The total flavonoid contents extracted from dried samples were shown in Table 3. The equation for calibration curve of the quercetin standard was $\mathrm{y}=0.037 \mathrm{x}+0.205$, with $\mathrm{R}^{2}=$ 0.994 .

Among the samples, Donax canniformis (G. Forst.) K. Schum (root and stem) showed the highest (11.95 mgQE/g) amount of total flavonoid content, , while the lowest $(0.01 \mathrm{mgQE} / \mathrm{g})$ ones was in Persicaria barbata (L.) H. Hara (herb) (Table 3).

\section{Total Phenolic Contents}

The total phenolic contents of the 21 aquatic plants samples were shown in Table 4. Based on total phenolic content analysis, we found that amount of total phenolic content ranged from $0,558 \mathrm{mgGAE} / \mathrm{g}$ to $8,864 \mathrm{mgGAE} / \mathrm{g}$. The highest amount of total phenolic contents was detected in Donax canniformis (G. Forst.) K. Schumin stem and rootpart of the plant. While the lowest amount of total phenolic content was detected in Murdannia sp.

\section{Antioxidant Activity}

Eight out of 21 aquatic plants samples were identified to have the ability to scavenge DPPH radicals. Of these, three samples, i.e Donax canniformis, Persicaria barbata, and Diplazium have high ability to scavenge free radicals compared to other samples. . The ability to scavenge free radicals is defined in terms of inhibition concentration $\left(\mathrm{IC}_{50}\right)$ as shown in Figure 2. 
Table 2. List of Phytochemical each aquatic plant from Bantimurung Bulusaraung South Sulawesi.

\begin{tabular}{|c|c|c|c|c|c|c|c|c|c|}
\hline \multirow{2}{*}{ No } & \multirow{2}{*}{ Species name } & \multirow{2}{*}{$\begin{array}{l}\text { Part of } \\
\text { plant }\end{array}$} & \multicolumn{7}{|c|}{ Phytochemical screening result } \\
\hline & & & Alkaloid & Flavonoid & Terpenoid & Phenol & Antraquinon & Saponin & Glycoside \\
\hline 1 & $\begin{array}{l}\text { Anadendrum microstachyum } \\
\text { (de Vriese \& Miq.) Backer } \\
\& \text { Alderw }\end{array}$ & Herbs & - & + & - & - & - & - & + \\
\hline 2 & $\begin{array}{l}\text { Donax canniformis } \\
\text { (G.Forst)K.Schum }\end{array}$ & Stem \& root & - & + & - & + & - & + & + \\
\hline 3 & $\begin{array}{l}\text { Donax canniformis } \\
\text { (G.Forst.) K.Schum }\end{array}$ & Leaf & - & + & - & + & - & + & + \\
\hline 4 & Diplazium & Herbs & - & + & - & + & - & + & + \\
\hline 5 & Elatostema sp & Leaf & - & + & - & - & - & - & + \\
\hline 6 & Epipremnum $\mathrm{sp}$ & Herbs & - & + & - & - & - & - & + \\
\hline 7 & Hemigraphis sp & Herbs & - & + & - & - & - & + & + \\
\hline 8 & Lindsaea scandens Hook & Herbs & - & + & - & - & - & - & + \\
\hline 10 & Oldelandia $\mathrm{sp}$ & Herbs & - & + & - & - & - & - & + \\
\hline 11 & $\begin{array}{l}\text { Stenosemia aurita (Sw.)C. } \\
\text { Presl }\end{array}$ & Leaf & - & + & - & - & - & - & + \\
\hline 12 & Staurogyne elongata Kuntze & Stem \& root & - & + & - & - & - & + & + \\
\hline 13 & Staurogyne elongata Kuntze & Leaf & - & + & - & - & - & - & + \\
\hline 14 & Staurogyne sp & Herbs & - & + & - & + & - & - & + \\
\hline 15 & $\begin{array}{l}\text { Schismatoglottis calyptrate } \\
\text { (Roxb.) Zoll.\& Moritzi }\end{array}$ & Herbs & - & + & - & - & - & - & + \\
\hline 16 & Schismatoglottis sp & Herbs & - & + & - & - & - & + & + \\
\hline 17 & $\begin{array}{l}\text { Selaginella plana (Desv. Ex } \\
\text { Poir) Hieron }\end{array}$ & Herbs & - & + & - & + & - & + & + \\
\hline 18 & Senna alata (L) Roxb. & Herbs & - & + & - & - & - & - & + \\
\hline 19 & $\begin{array}{l}\text { Persicaria barbata }(\mathrm{L}) \mathrm{H} . \\
\text { Hara }\end{array}$ & Herbs & - & + & - & + & - & + & + \\
\hline 21 & Pothos tener Wall & Herbs & - & + & - & + & - & - & + \\
\hline
\end{tabular}

Based on antioxidant activity extracted from the leaf of Donnax canniformis (G. Forst.) K. Schum, an observed inhibition concentration of $\mathrm{IC}_{50}$ value was $67.053 \mu \mathrm{g} / \mathrm{mL}$ and that of While, extracted from from the herbs part of Persicaria barbata resulted in $73.745 \mu \mathrm{g} / \mathrm{mL}$ of the $\mathrm{IC}_{50}$ concentration value. While, antioxidant activity obtained from the Diplazium spp. extracted from herbs part was $90.292 \mu \mathrm{g} / \mathrm{mL}$ of the $\mathrm{IC}_{50}$ concentration value. These three aquatic plant samples would be potentially used for future purposes to prevent free radicals.

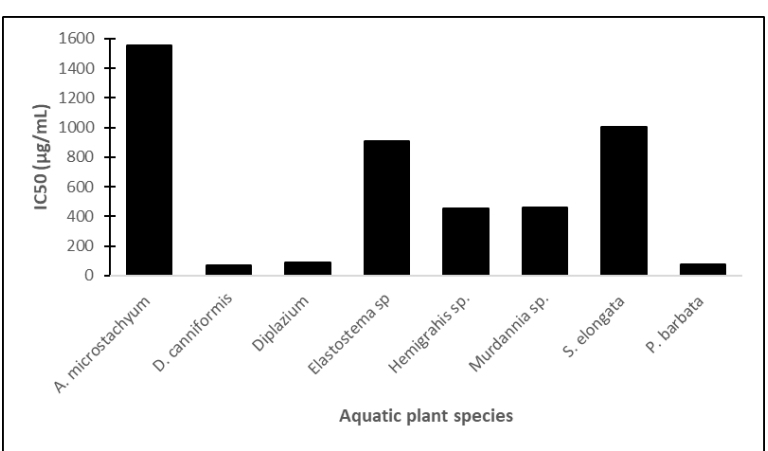

Figure 2. Histogram of antioxidant activity obtained from 8 aquatic plant species collected in Bantimurung Bulusaraung.

\section{Discussion}

Based on botanical identification, all aquatic plant samples collected in Bantimurung waterfalls were successfully identified. To our best knowledge, identification study of aquatic plants live at the Bantimurung waterfalls was not reported and this finding was the first report in relation to their botanical names. Prior to the phytochemical compound analysis, present study indicated that two major compounds, including flavonoid and glycoside were detected and all the samples. Two phytochemical compounds such as phenols, and saponin were mostly detected in several aquatic plant samples and no alkaloid, terpenoid and antraquinon were detected.. In current study, for example, Donnax canniformis which showed the highest amount of total flavonoid and phenolic contents with high antioxidant activity could be potentially used as source of herbal medicine. 
Table 3. Total flavonoid content each species aquatic plant.

\begin{tabular}{|c|c|c|c|}
\hline No & Species Name & Part of Plant & $\begin{array}{l}\text { Total Flavonoid } \\
\text { Contents }(\mathrm{mgQE} / \mathrm{g})\end{array}$ \\
\hline 1 & $\begin{array}{l}\text { Anadendrum microstachyum (de Vriese \& } \\
\text { Miq.) Backer \& Alderw }\end{array}$ & Herbs & 5,03 \\
\hline 2 & Donax canniformis (G.Forst.) K. Schum. & Stem \& root & 11,95 \\
\hline 3 & Donax canniformis (G.Forst.) K. Schum. & Leaf & 3,95 \\
\hline 4 & Diplazium & Herbs & 4,26 \\
\hline 5 & Elatostema $\mathrm{sp}$ & leaf & 10,01 \\
\hline 6 & Epipremnum sp & Herbs & 0,07 \\
\hline 7 & Hemigraphis sp & Herbs & 2,42 \\
\hline 8 & Lindsaea scandens Hook. & Herbs & 4,53 \\
\hline 9 & Murdannia sp & Herbs & 0,84 \\
\hline 10 & Oldelandia sp & Herbs & 1,29 \\
\hline 11 & Stenosemia aurita (Sw.) C. Presl & Leaf & 2,18 \\
\hline 12 & Staurogyne elongata Kuntze & Stem \& root & 0,18 \\
\hline 13 & Staurogyne elongata Kuntze & Leaf & 7,70 \\
\hline 14 & Staurogyne sp & Herbs & 11,4 \\
\hline 15 & $\begin{array}{l}\text { Schismatoglottis calyptrata (Roxb.) Zoll. } \\
\text { \& Moritzi }\end{array}$ & Herbs & 1,49 \\
\hline 16 & Schismatoglottis sp & Herbs & 4,01 \\
\hline 17 & Selaginella plana (Desv. Ex Poir.) Hieron. & Herbs & 11,84 \\
\hline 18 & Senna alata $(\mathrm{L}$.$) Roxb$ & Herbs & 2,27 \\
\hline 19 & Persicaria barbata (L.) H.Hara & Herbs & 0,01 \\
\hline 20 & Pellionia sp & Herbs & 5,57 \\
\hline 21 & Pothos tener Wall & Herbs & 7,16 \\
\hline
\end{tabular}

However, to meet this purpose, the detailed further study is still needed. Similarly, the two aquatic plants such as Persicaria barbata and Diplazium esculentum were also promisingly sources of new herbal medicine plants. They showed a good ability to possess antioxidant activity with the $\mathrm{IC}_{50}$ values of less than $100 \mu \mathrm{g} / \mathrm{mL}$. The phenolic and flavonoid compounds available in Diplazium esculentum species could potentially play a key role in inhibiting DPPH free radicals. Maisuthisakul (2012) reported that flavonoid compounds contained a number of phenolic hydroxyl groups attached to aromatic ring structures, which confer the antioxidant activity. Flavonoids inhibit antioxidant in four ways, consisting of (1) quenching free radical elements, (2) chelating metal, (3) suppressing the enzymes associated with free radical generation, and (4) stimulating internal antioxidant enzymes (Banjarnahor \& Artanti., 2014).
Overall, our present study implied that identification of the phytochemical compounds in aquatic plants, especially in Indonesia should be considered as an important aspect to study. Aquatic plants could also potentially be used as source of herbal medicine and to take advantage of their future purposes the detailed further study is still needed.

\section{CONCLUSION}

A total of 21 aquatic plants species names were succesfully identified in present study. Phytochemical compound analysis of the aquatic plants resulted in 4 major components including flavonoid, phenol, saponin and glycoside. Three aquatic plant species Donax canniformis (G.Forst.) K. Schum., Diplazium, Persicaria barbata were found to have a high antioxidant activity, which beneficial to attack free radicals. 
Table 4. Total Phenolic Contents from each species of aquatic plants.

\begin{tabular}{|c|c|c|c|}
\hline No & Species Name & Part of Plant & $\begin{array}{l}\text { Total Phenolic } \\
\text { Contents } \\
(\text { mgGAE/g) }\end{array}$ \\
\hline 1 & $\begin{array}{l}\text { Anadendrum microstachyum (de } \\
\text { Vriese \& Miq.) Backer \& Alderw }\end{array}$ & Herbs & 3,933 \\
\hline 2 & $\begin{array}{l}\text { Donax canniformis (G.Forst.) K. } \\
\text { Schum. }\end{array}$ & Stem \& root & 8,864 \\
\hline 3 & $\begin{array}{l}\text { Donax canniformis (G.Forst.) K. } \\
\text { Schum. }\end{array}$ & Leaf & 7,071 \\
\hline 4 & Diplazium & Herbs & 6,185 \\
\hline 5 & Elatostema $\mathrm{sp}$ & Leaf & 3,252 \\
\hline 6 & Epipremnum sp & Herbs & 0,775 \\
\hline 7 & Hemigraphis sp & Herbs & 0,862 \\
\hline 8 & Lindsaea scandens Hook. & Herbs & 1,348 \\
\hline 9 & Murdannia sp & Herbs & 0,558 \\
\hline 10 & Oldelandia sp & Herbs & 0,621 \\
\hline 11 & Stenosemia aurita (Sw.) C. Presl & Leaf & 0,924 \\
\hline 12 & Staurogyne elongata Kuntze & Stem \& root & 3,471 \\
\hline 13 & Staurogyne elongata Kuntze & Leaf & 0,629 \\
\hline 14 & Staurogyne sp & Herbs & 0,791 \\
\hline 15 & $\begin{array}{l}\text { Schismatoglottis calyptrata (Roxb.) } \\
\text { Zoll. \& Moritzi }\end{array}$ & Herbs & 0,733 \\
\hline 16 & Schismatoglottis $\mathrm{sp}$ & Herbs & 2,106 \\
\hline 17 & $\begin{array}{l}\text { Selaginella plana (Desv. Ex Poir.) } \\
\text { Hieron. }\end{array}$ & Herbs & 2,857 \\
\hline 18 & Senna alata (L.) Roxb & Herbs & 2,026 \\
\hline 19 & Persicaria barbata (L.) H.Hara & Herbs & 6,52 \\
\hline 20 & Pellionia sp & Herbs & 5,903 \\
\hline 21 & Pothos tener Wall & Herbs & 8,519 \\
\hline
\end{tabular}

\section{Acknowledgements}

The Authors are grateful thank to Insinas KEMENRISTEK DIKTI for financial support during the various expedition and research aquatic plant in Sulawesi for 2017-2018. We also greatly thanks to Prof Andi Akhmad Mustafa Chairman Balai Riset Perikanan Budidaya Air Payau dan Penyuluhan - BRSDM KKP Maros, Dr. Darmawan, Director of Politeknik Negeri Pangkep South Sulawesi, Ir. Mastur, Ph.D Chairman of Indonesian Center for Agricultural for Biotechnology and Genetic Resources Research and Development , Dr. Idil
Ardi Chairman of Indonesian Riset center for ornamental fish. Dr. Andi Parenrengi, Debora Ayu Christyandari, AMD, and Daswar. We also thanks to the people of South Sulawesi who have helped us and all of heads o regions in the area of South Sulawesi.

\section{References}

Ahmad, I., Yanuar, A., Mulia, K., Mun'im, A. (2017). Application of ionic liquid as a green solvent for polyphenolics content extraction of Peperomia Pellucida (L) Kunth Herb. J Young Pharm. 9(4):486-90. DOI: 10.5530/jyp.2017.9.95. 
Alahuhta, J., Kosten, S., Akasaka, M., Auderset, D., Azzella, M,M., Bolpagni, R., et al. (2017). Global variation in the beta diversity of lake macrophytes is driven by environmental heterogeneity rather than latitude. Journal of Biogeography . 44 1758-1769. doi: 10.1111/jbi.12978.

Ansari, A,A., Saggu, S., MAl-Ghanim, S., Abbas, Z,K., Gill, S,S., Khan, F,A., Dar, M,I., Naikoo,M,I., and Khan, A,A. (2017). Aquatic Plant Biodiversity: A Biological Indicator for the Monitoring and Assessment of Water Quality. $C A B$ International. $\mathrm{p} 218-227$.

Banjarnahor, S,D,S \& Artanti, N. (2014). Antioxidant properties of flavonoids. Med J Indones. 23(4), 239-244.

Bobo-garcía, G., Davidov-pardo, G., Arroqui, C., \& Marín-arroyo, M,R. (2014). Intra-laboratory validation of microplate methods for total phenolic content and antioxidant activity on polyphenolic extracts, and comparison with conventional spectrophotometric methods. J Sci Food Agric.2014; http://doi.org/10.1002/jsfa.6706.

Bouma, T,J., De Vries, M,B., Herman P,M,J. (2010). Comparing ecosystem engineering efficiency of two plant species with contrasting growth strategies. Ecology. 1010; 91(9), 2696-2704. doi: 10.1890/09-0690.1.

Chambers, P,A., lacoul, P., Murphy, K,J., Thomaz ,S,M. (2008). Global diversity aquatic macrophytes in freshwater. Hidrobiologia. 595:926. DOI: 10.1007/S10750-007-9154-6.

Departemen Kesehatan Republik Indonesia. (1995b). Materia Medika Indonesia Jilid V. Jakarta: Departemen Kesehatan Republik Indonesia.

Gersberg, R,M., Elkins, B,V., Lyon, S,R., Goldman, C,R. (1986). Role of aquatic plants in waste water treatment by artificial wetland. Pergamon Press Ltd.. Wat. Res. 20(3): 363-368.

Gopal, B. (2013). Future of wetlands in tropical and subtropical Asia, especially in the face of climate change. Aquat Sci. 75: 39-61 DOI 10.1007/s00027-011-0247-y.
Harborne, J. B. (1998). Phytochemical methods: a guide to modern techniques of plant analysis. London: Chapman \& Hall.

Maisuthisakul, P. (2012). Phenolic Constituents and Antioxidant Properties of Some Thai Plants. In : Rao, Venkeketeshwer. Phytochemicals - A Global Perspectives of Their Role in Nutrition and Health. Croatia :Intech. p : 187-213.

Parenti, L,R. (1998). Neostethus djajaorum, new species from Sulawesi Indonesia, The first Phallostethid Fish (Teleostei: Atherinomorpha) known from east of Wallace's line. The Raffles Bulletin of Zoology. 46(1): 139-150

Saunders, D,L., Meuwig, J,J., Vincent, A,C,J. (2002). Freshwater Protected Areas : Strategies for Conservation. Conservation Biology. p. 30-41. https://doi.org/10.146/j.1523-1739.2002.99526.x.

Scheffer, M., Szabo' S., Gragnani, A., van Nes, E,H., Rinaldi, S., Kautsky, N., Norberg, J., Roijackers, R,M,M., Franken, R,J,M. (2003). Floating plant dominance as a stable state . PNAS 100 (7) 40404045. Proc. Natl. Acad. Sci. U.S.A. www.pnas.org.cgi.doi.10.1073.pnas.0737918100.

Thomaz, SM., \& Da Cunha, E,R. (2010). The role of macrophytes in habitat structuring in aquatic ecosystems: methods of measurement, causes and consequences on animal assemblages' composition and biodiversity. Acta Limnologica Brasiliensia. 22(2) p. 218-236. doi: 10.4322/actalb.02202011.

Wakka, A,K., Awang, S,A., Purwanto,R,H., Poedjirahajoe, E. (2012). Analisa kondisi social ekonomi masyarakat sekitar taman nasional Bantimurung Bulusarung, Provinsi Sulawesi selatan. Journal Manusia \& lingkungan. 19(1): 111.

Xu, Z., Yan, B., He, Y \& Song, C. (2007). Nutrient limitation and wetland botanical diversity in Northeast China: can fertilization influence on species richness? Soil Science. 2007 ; 172, 86-93. 